\title{
Optimization and Evaluation of Hybrid PV/WT/BM System in Different Initial Costs and LPSP Conditions
}

\author{
Abdülsamed Tabak \\ Department of Energy Systems Engineering \\ Karabuk University \\ Karabuk \\ Mehmet Özkaymak \\ Department of Energy Systems Engineering \\ Karabuk University \\ Karabuk
}

\author{
Muhammet Tahir Güneşer \\ Department of Electrical and Electronics Engineering \\ Karabuk University \\ Karabuk
}

Hüseyin Oktay Erkol

Department of Mechatronics Engineering

Karabuk University

Karabuk

\begin{abstract}
A modelling and optimization study was performed to manage energy demand of a faculty in Karabuk University campus area working with a hybrid energy production system by using genetic algorithm (GA). Hybrid system consists of photovoltaic (PV) panels, wind turbines (WT) and biomass (BM) energy production units. Here BM is considered as a back-up generator. Objective function was constituted for minimizing total net present cost (TNPC) in optimization. In order to obtain more accurate results, measurements were performed with a weather station and data were read from an electricity meter. The system was also checked for reliability by the loss of power supply probability (LPSP). Changes in TNPC and localized cost of energy (LCOE) were interpreted by changing LPSP and economic parameters such as PV investment cost, WT investment cost, $B M$ investment cost, and interest rates. As a result, it was seen that a hybrid system consisted of PV and BM associated with an effective flow algorithm benefited from a GA meets the energy demand of the faculty.
\end{abstract}

Keywords-photovoltaic (PV)/wind turbines (WT)/ biomass (BM); hybrid system; optimization; sizing; cost-effective; reliability; genetic algorithm

\section{INTRODUCTION}

Recently, as energy demand increases, fossil-based energy sources are running out. Usage of renewable energy sources such as solar, wind and hydroelectric, become widespread as an alternative to the depleting fossil resources [1]. Despite the widespread use of renewable energy sources, they are still not cost-effective as conventional energy sources [2]. For this reason, some economic and reliability calculations must be taken into consideration before investment.

Renewable energy sources are used as hybrid systems to reduce investment costs and increase system reliability. Because, when they are used individually, some disadvantages arise due to their stochastic properties whereas, these disadvantages disappear when they are used as hybrid systems [3], [4]. If renewables are used as hybrids, optimum sizing studies can be done according to the variable load. During sizing studies, the objective function is constituted, and mathematical calculations are performed to obtain the lowest value of this function [5].

In sizing studies, objective function is generally considered as cost equations. Total net present cost (TNPC), total annualized cost (TAC) and localized cost of energy (LCOE) are the most common economic evaluation methods. TNPC is sum of net present cost (NPC) of the components. These components are initial investment cost (IC), operating and maintenance costs $(\mathrm{OM})$, fuel costs (FC) and salvage values (S) [6]. TAC expresses the annual cost of TNPC [7]. LCOE is energy cost per kWh [6]. Economic analyses such as TNPC [8]-[10], TAC [11] and LCOE [9] are frequently used in literature.

In hybrid energy generation systems, high reliability of the system is as important as cost-effectiveness. Meeting of load by generated energy refers to a reliable system. Loss of power supply probability (LPSP) is a reliability evaluation method and was proposed by [12]. Researchers are frequently using LPSP for reliability of hybrid systems [9], [11]. Other reliability parameters such as loss of energy expectation (LOEE) used in [8] and energy index of reliability (EIR) used in [10] study.

Most of hybrid systems consist of PV panels, WT, batteries, diesel generators and fuel cells are evaluated according to economy and reliability. Optimization problems in these studies were solved by different meta-heuristic methods such as artificial bee colony, genetic algorithm, harmony search and particle swarm optimization [4], [8], [13], [15]. In literature, small number of studies includes BM. [14][20]. In addition, optimization problems were solved by readysoftware such as HOMER [16]-[20]. For instance, in the studies [14], [15]; mixed integer linear programming and harmony search were used to solve optimization problem. In 
these studies wind energy was not included in the hybrid system.

However, HOMER has some disadvantages such as usage of a single objective function to reduce net present cost to minimum, usage of non-sorted results by LCOE when doing an evaluation according to NPC, performing without considering depth of discharge for batteries and ignoring hourly changes [21].

Suganthi et al. express that in recent years optimization studies involving solar and wind energy systems have been frequently performed. In addition, despite the start of bioenergy studies with solar and wind energy, there is still a large gap in researches about optimization of hybrid energy systems including bioenergy [22].

In this study, PV/WT/BM were hybridized and optimized with GA for the first time. For this purpose, number of PV panel, sweeping area of WT and power of biogas (BG) generator were selected as optimization parameters due to the major effects on the total system efficiency. BM based PV/WT hybrid energy production system was optimized according to the minimum value of TNPC to meet variable load. Results were also evaluated in terms of LCOE and cost per $\mathrm{kWh}$ was calculated. In addition, reliability was controlled by setting LPSP to maximum 0.1. Furthermore, results for TNPC and LCOE were interpreted with different LPSP values under the operating conditions with different economic parameters such as different initial cost of PV, WT, BM, and interest rates.

This paper was organized as follows: Section 2 described scientific fundamentals and experimental studies consisting of weather and electrical measurements to prepare the required data for the simulation input. Section 3 presented and evaluated the optimization results according to the different economic parameters. Finally, conclusion was conferred in Section 4.

\section{Methodology AND Mathematical ModELling}

In this section, measurement values, constant values and mathematical models of $\mathrm{PV} / \mathrm{WT} / \mathrm{BM}$ were revealed for optimization study. In addition, mathematical models of economic evaluation method were suggested to determine objective function. Work flow of optimization study was presented to understand system working principle.

\section{A. Obtaining of Data}

Hourly radiation, temperature and wind speed was obtained from the weather station and instantaneous changing of the load was taken from electricity meter of Faculty of Economics and Administrative Sciences which shown in Fig. 1. For biomass source of the hybrid system, waste of student and staff dining hall of Karabuk University, waste of dining hall of Kardemir Corporation, waste of Training and Research Hospital dining hall of Karabuk University and grass quantity of campus area were used. Possible waste quantity per person and rate of methane for these wastes were taken from [23] and [24]. Biogas production potential of these wastes was given in Table 1.

Table 1 shows the number of meals, amount of waste, produced $\mathrm{BG}$ and methane. The number of meal was taken from dining halls personnel and produced amount of BG and methane were taken from [24]. In addition to food wastes BG production of grass wastes were given as in Table 2 .

Table 2 shows the amount of grass wastes, produced BG and methane. Annual amount of grass wastes in campus area was taken from technical personnel of university and produced amount of BG and methane were taken from [25], [26].
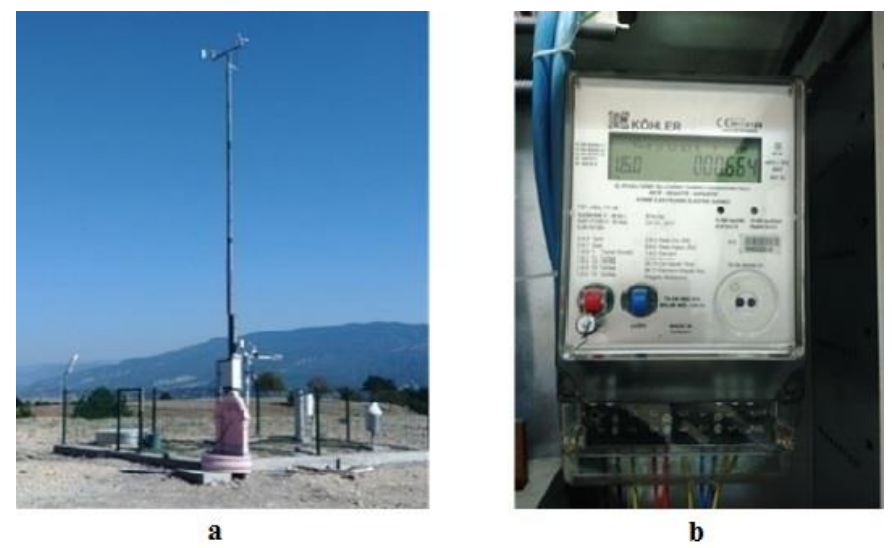

Fig. 1. Weather station (a) and electricity meter (b).

TABLE I. BIOGAS Production Potential of WAStes

\begin{tabular}{|l|l|l|l|l|l|}
\hline Location & $\begin{array}{l}\text { Number of meals } \\
\text { (piece/year) }\end{array}$ & $\begin{array}{l}\text { Total amount of waste } \\
\text { (kg/year) }\end{array}$ & $\begin{array}{l}\text { Produced amount of } \\
\text { biogas }\left(\mathbf{m}^{3} / \text { year }\right)\end{array}$ & $\begin{array}{l}\text { Methane ratio in } \\
\text { biogas }[\mathbf{2 4}]\end{array}$ & $\begin{array}{l}\text { Produced amount of } \\
\text { methane }\left(\mathbf{m}^{3} / \mathbf{y e a r}\right)\end{array}$ \\
\hline Dining Halls & 3699286 & 350026.44 & 85756.46 & $64 \%$ & 54884.13 \\
\hline
\end{tabular}

TABLE II. BIOGAS Production Potential of Grass WAStes

\begin{tabular}{|c|c|c|c|c|c|}
\hline Location & $\begin{array}{l}\text { Obtained quantity } \\
\text { (kg/year) }\end{array}$ & $\begin{array}{l}\text { Produced biogas (L) } \\
{[25-26]}\end{array}$ & $\begin{array}{l}\text { Produced amount of } \\
\text { biogas }\left(\mathrm{m}^{3} / \text { year }\right)\end{array}$ & $\begin{array}{l}\text { Methane ratio in } \\
\text { biogas [26] }\end{array}$ & $\begin{array}{l}\text { Produced amount of } \\
\left.\text { methane ( } \mathbf{m}^{3} / \text { year }\right)\end{array}$ \\
\hline Grass on Campus & 165000 & 82500000 & 82500 & $70 \%$ & 57750 \\
\hline
\end{tabular}


TABLE III. TECHNICAL AND ECONOMIC PARAMETERS OF HYBRID SYSTEM

\begin{tabular}{|c|c|c|}
\hline Parameters & Unit & Value \\
\hline Interest Rate (i) & - & 0.1 \\
\hline Lifespan of Project (N) & year & 25 \\
\hline Inflation Rate & - & 0.0805 \\
\hline Escalation Rate of PV System & - & 0.09 \\
\hline Escalation Rate of Wind Turbine & - & 0.09 \\
\hline $\begin{array}{l}\text { Escalation Rate of Biogas } \\
\text { System }\end{array}$ & - & 0.05 \\
\hline $\begin{array}{l}\text { Investment cost of PV System } \\
\left(\alpha_{\mathrm{pv}}\right)\end{array}$ & (\$/piece) & 385.71 \\
\hline $\begin{array}{l}\text { Operating and Maintenance Cost } \\
\text { of the PV System }\end{array}$ & (\$/piece/year) & $0.011 \mathrm{x} \alpha_{\mathrm{pv}}$ \\
\hline Salvage Value of PV System & (\$/piece) & $0.2 \times \alpha_{\mathrm{pv}}$ \\
\hline $\begin{array}{l}\text { Maximum power temperature } \\
\text { coefficient }\left(\mathrm{K}_{\mathrm{p}}\right)\end{array}$ & $\left(\% /{ }^{\circ} \mathrm{C}\right)$ & -0.42 \\
\hline $\begin{array}{l}\text { Temperature in Standard Test } \\
\text { Condition }\left(\mathrm{T}_{\mathrm{R}}\right)\end{array}$ & $\left({ }^{\circ} \mathrm{C}\right)$ & 25 \\
\hline $\begin{array}{l}\text { Investment cost of Wind Turbine } \\
\alpha_{w t}\end{array}$ & $(\$ / \mathrm{m} 2)$ & 480 \\
\hline Salvage Value of Wind Turbine & $(\$ / \mathrm{m} 2)$ & $0.1 \times \alpha_{w t}$ \\
\hline $\begin{array}{l}\text { Annual Operating and } \\
\text { Maintenance Cost of the Wind } \\
\text { Turbine }\end{array}$ & $\left(\$ / \mathrm{m}^{2} /\right.$ year $)$ & $0.0109 \times \alpha_{w t}$ \\
\hline $\begin{array}{l}\text { Investment cost of Biogas } \\
\text { System } \alpha_{\mathrm{bg}}\end{array}$ & $(\$ / \mathrm{kW})$ & $2438.45[27]$ \\
\hline $\begin{array}{l}\text { Fixed Operation and } \\
\text { Maintenance Cost of Biogas } \\
\text { System }\end{array}$ & (\$/kW/year) & $0.045 \mathrm{x} \alpha_{\mathrm{bg}}$ \\
\hline $\begin{array}{l}\text { Variable Operation and } \\
\text { Maintenance Cost of Biogas } \\
\text { System }\end{array}$ & (\$/kWh/year) & 0.0351 \\
\hline Fuel Cost of Biogas System & $\left(\$ / \mathrm{m}^{3} /\right.$ year $)$ & 0.1657 \\
\hline Salvage Value of Biogas System & $(\$ / \mathrm{kW})$ & $0.3 \times \alpha_{\mathrm{bg}}$ \\
\hline Efficiency of Biogas Generator & - & 0.41 \\
\hline Methane ratio in biogas & - & 0.64 \\
\hline Lower Heating Value of Biogas & $\left(\mathrm{kWh} / \mathrm{m}^{3}\right)$ & 6.4 \\
\hline Number of PV Panels ( $\left.\mathrm{N}_{\text {module }}^{\text {max }}\right)$ & Piece & 1000 \\
\hline $\begin{array}{l}\text { Maximum Area for Wind } \\
\text { Turbines }\left(A_{w t}^{\max }\right)\end{array}$ & $\left(\mathrm{m}^{2}\right)$ & 1000 \\
\hline $\begin{array}{l}\text { Maximum Power of Biogas } \\
\text { Generator }\left(\mathrm{P}_{\mathrm{bg}}^{\max }\right)\end{array}$ & $(\mathrm{kW})$ & 100 \\
\hline Maximum LPSP (LPSP ${ }^{\max }$ ) & - & 0.01 \\
\hline
\end{tabular}

Simplified diagram of hybrid system was shown in Fig. 2. Relative frequency of radiation $\left(\mathrm{W} / \mathrm{m}^{2}\right)$, wind speed $(\mathrm{m} / \mathrm{s})$, weather temperature $\left({ }^{\circ} \mathrm{C}\right)$ and load period $(\mathrm{W})$ were given in Fig. 3. Technical and economic parameters of hybrid system were listed in Table 3 . The parameters were taken from literature [15], [24], [27]-[30].

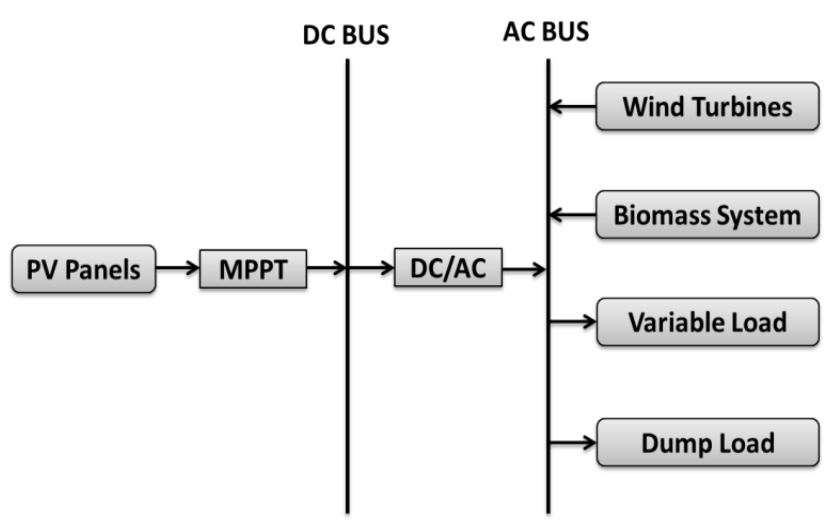

Fig. 2. Simplified diagram of hybrid system.

\section{B. Modelling of PV Power}

Power generating systems can be represented by different mathematical methods. In this study, following equations were utilized for power model of PV panel.

$T_{C}(t)=T_{A}(t)+\frac{N O C T-20}{800} R(t)$

$P_{p v}(t)=N_{\text {module }} \cdot V_{m p p} . I_{m p p} \times \frac{R}{1000}\left[1-\frac{K_{p}}{100}\left(T_{C}(t)-T_{R}\right)\right](2)$

Where, $T_{C}(t)$ is cell temperature, $T_{A}(t)$ is ambient temperature, $R(t)$ is radiation and NOCT is nominal operation cell temperature in (1). $P_{p v}(t)$ is power in maximum power tracking point, $N_{\text {module }}$ is number of total modules, $K_{p}$ is maximum power temperature coefficient $\left(\% /{ }^{\circ} \mathrm{C}\right), T_{R}$ is cell temperature in standard test conditions, and maximum power point voltage and current are $V_{m p p}$ and $I_{m p p}$, respectively in (2).

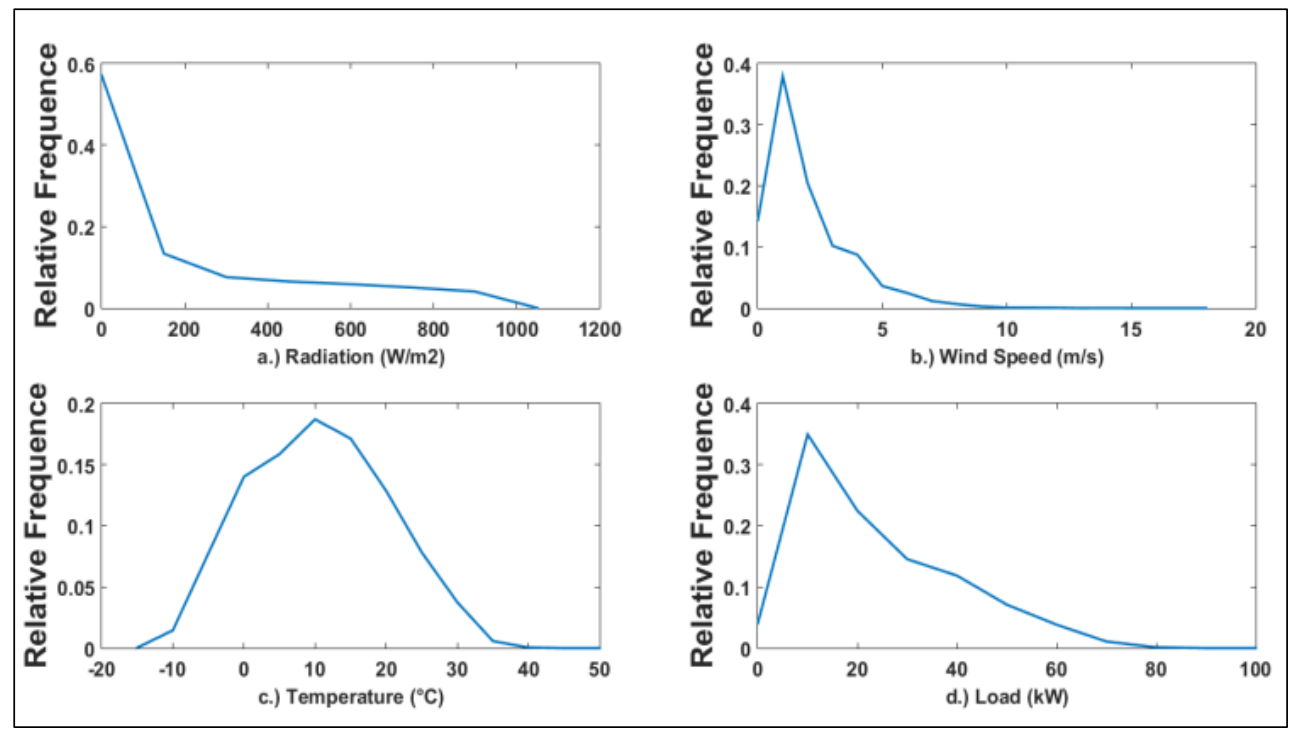

Fig. 3. Relative frequency of radiation $(\mathrm{W} / \mathrm{m} 2)(\mathrm{a})$, wind speed $(\mathrm{m} / \mathrm{s})(\mathrm{b})$, ambient temperature $\left({ }^{\circ} \mathrm{C}\right)(\mathrm{c})$ and load period $(\mathrm{W})(\mathrm{d})$. 


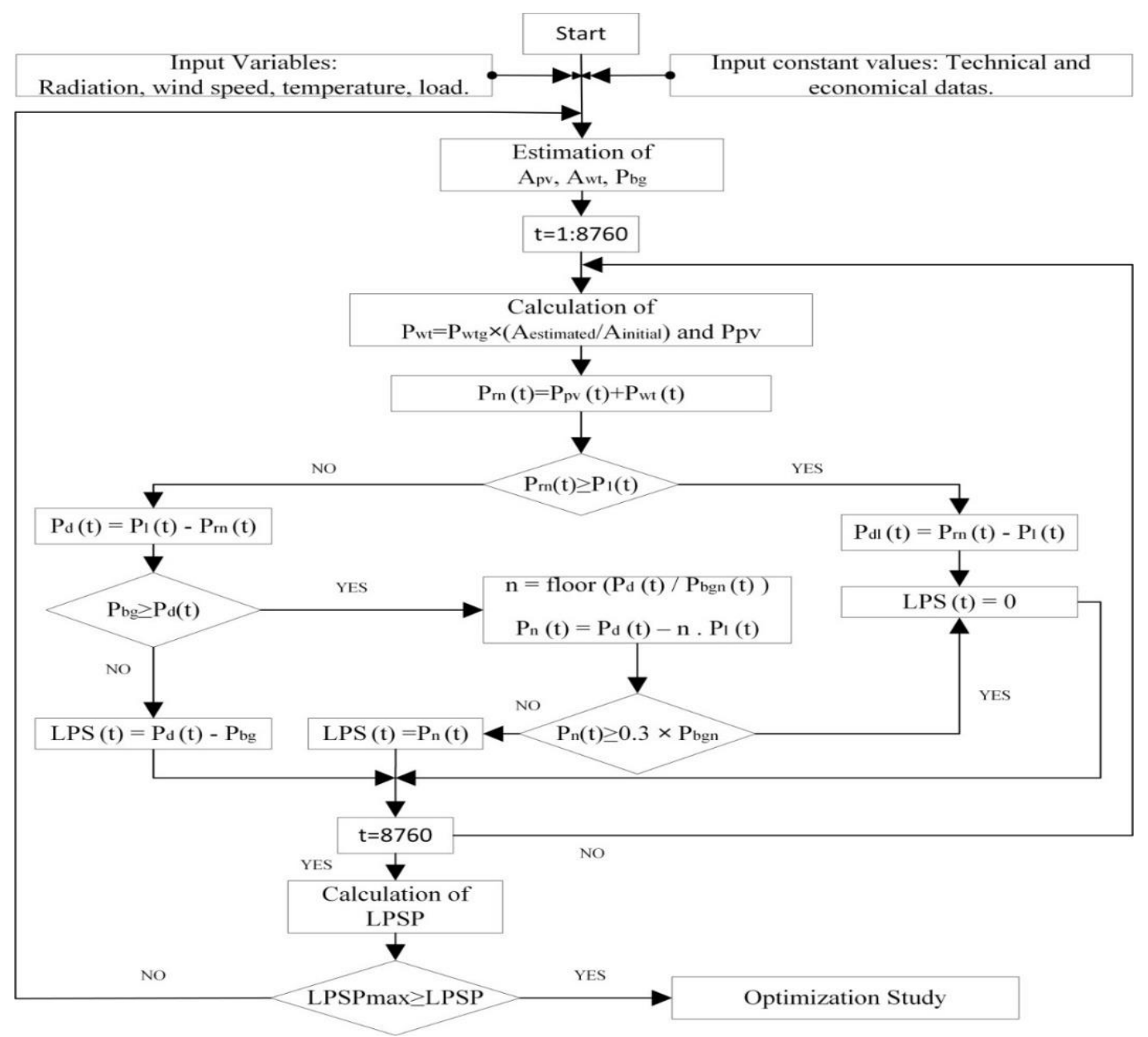

Fig. 4. Work flow of optimization.

\section{Modelling of Wind Turbine Power}

For the modelling step of WT power, (3) was used. In (3), $P_{r}$ is nominal power of WT, $A_{w t}$ is sweeping area of turbine, $V_{r}$ is speed in nominal power. $\rho_{\text {air }}$ indicates air density and was taken as $1.225 \mathrm{~kg} / \mathrm{m}^{3}$.

$$
P_{r}=\frac{1}{2} \times \rho_{\text {air }} \times A_{w t} \times V_{r}^{3} \times C p
$$

In order to obtain power of WT $\left(P_{W T G}\right)$ more accurately under different wind speed conditions, (4) was used as given below. In (4), $V_{c i}$ is cut in speed for turbine $(\mathrm{m} / \mathrm{s})$ and $V_{c o}$ is cut out speed for turbine $(\mathrm{m} / \mathrm{s})[31]$.

$$
\mathrm{P}_{\mathrm{WTG}}=\left\{\begin{array}{lr}
0, & V<V_{c i} \\
a \times V^{3}-b \times P_{r,} & V_{c i} \leq V<V_{r} \\
P_{r}, & V_{r} \leq V \leq V_{c o} \\
0, & V>V_{c o}
\end{array}\right.
$$

$a$ and $b$ coefficients were given below:

$$
a=\frac{P_{r}}{V_{r}^{3}-V_{c i}^{3}} \quad b=\frac{V_{c i}^{3}}{V_{r}^{3}-V_{c i}^{3}}
$$

Output power of WT is updated according to the estimated sweeping area of turbine. $P_{w}(\mathrm{~W})$ shows the updated output power of turbine and takes a new value in every iteration.

$$
P_{w}=P_{W T G} \times\left(\frac{A_{w t}}{A_{\text {initial }}}\right)
$$

In (6), $A_{\text {initial }}$ is initial sweeping area of turbine $\left(\mathrm{m}^{2}\right)$ and $A_{w t}$ is sweeping area $\left(\mathrm{m}^{2}\right)$ of WT estimated by genetic algorithm.

\section{Modelling of Biogas Generator Power}

In this study, when energy production from PV panels and WT became insufficient, a back-up BG generator runs. A mathematical model to determine the dimensions of $\mathrm{BG}$ generator was developed as given in (7) [15], [32].

$$
P_{b g}(t)=\eta_{b g} \times Q_{b g}(t) \times L H V_{b g}
$$

Where, $P_{b g}$ is power of biogas generator (W), $\eta_{b g}$ is efficiency of generator, $Q_{b g}(t)$ is amount of biogas consumption $\left(\mathrm{m}^{3} / \mathrm{h}\right)$, and $L H V_{b g}$ is lower heating value of biogas $\left(\mathrm{kWh} / \mathrm{m}^{3}\right)$.

According to the hourly working power of generator, required amount of biogas was calculated as follows:

$$
Q_{b g}(t)=\frac{P_{b g, h}(t)}{\eta_{b g} \times L H V_{b g}}
$$

Where, $P_{b g, h}(t)$ is power of biogas generator at $t$ hour. 
Technical information of PV panels, WT and BG generator were shown in Table 4.

TABLE IV. TECHNICAL INFORMATION OF PV PANEL, WT AND BIOGAS GENERATOR

\begin{tabular}{|l|l|l|}
\hline \multirow{4}{*}{ PV Panel } & PV Panel Manufacturer & Yingli Solar \\
\cline { 2 - 3 } & Model & YL265P-29b \\
\cline { 2 - 3 } & Rated Power $(\mathrm{W})$ & 265 \\
\cline { 2 - 3 } & Panel Area $\left(\mathrm{m}^{2}\right)$ & \multicolumn{1}{|c|}{1.63} \\
\cline { 2 - 3 } & $\begin{array}{l}\text { Nominal Operation Cell Temperature } \\
\left({ }^{\circ} \mathrm{C}\right)\end{array}$ & $46+/-2$ \\
\hline \multirow{5}{*}{$\begin{array}{l}\text { Wind } \\
\text { Turbine }\end{array}$} & Wind Turbine Manufacturer & Halbes \\
\cline { 2 - 3 } & Wind Turbine Efficiency (\%) & 31.9 \\
\cline { 2 - 3 } & Pr $(\mathrm{kW})$ & 10 \\
\cline { 2 - 3 } & Vr $(\mathrm{m} / \mathrm{s})$ & 11 \\
\cline { 2 - 3 } & Vci $(\mathrm{m} / \mathrm{s})$ & 2.5 \\
\cline { 2 - 3 } & Vco $(\mathrm{m} / \mathrm{s})$ & 25 \\
\cline { 2 - 3 } & Rotor Diameter $(\mathrm{m})$ & 7.5 \\
\hline \multirow{5}{*}{ Giogas } & Generator Manufacturer & NPT \\
\cline { 2 - 3 } & Model & $10 \mathrm{GFT}$ \\
\cline { 2 - 3 } & Alternator Manufacturer & MBH(Germany) \\
\cline { 2 - 3 } & Nominal Power (kW/kVA) & $10 / 12.5$ \\
\cline { 2 - 3 } & Rated Speed $(\mathrm{r} / \mathrm{min})$ & 0.8 \\
\cline { 2 - 3 } & Power Factor & \\
\hline
\end{tabular}

\section{E. Total Net Present Cost (TNPC) of Hybrid System}

TNPC economic analysis method was used for economic evaluation of the hybrid energy system. TNPC is sum of net present costs of all costs over lifetime of the hybrid energy system as given in (9).

$$
T N P C=I C+O M+F C-S
$$

Here, $I C$ is investment cost, $O M$ is NPC of operating and maintenance costs, $F C$ is NPC of fuel costs, $S$ is NPC of salvage value of hybrid systems.

The TNPC for PV system, WTs and BG system were shown in (10)-(12), respectively. Fuel cost was not written in TNPC equation due to not existence fuel consumption in PV systems.

$$
\begin{aligned}
& T N P C_{p v}=I C_{p v}+O M_{p v}-S_{p v} \\
& T N P C_{w t}=I C_{w t}+O M_{w t}-S_{w t} \\
& T N P C_{b g}=I C_{b g}+O M_{b g}+F C_{b g}-S_{b g}
\end{aligned}
$$

In contrary to PV systems, fuel cost must be considered in $\mathrm{BM}$ systems. In addition, both fixed and variable costs were considered for operating and maintenance costs in BG system.

\section{F. Loss of Power Supply Probability}

Reliability of hybrid system was tested by LPSP method. It is one the most common reliability test and was shown in (13) [18]. Calculation of hourly LPS was explained in "methodology of optimization process".

$$
L P S P=\frac{\sum_{t=1}^{T} \operatorname{LPS}(t)}{\sum_{t=1}^{T} P_{l}(t)}
$$

\section{G. Objective Function and Constarints}

Objective function of optimization study was given in (14). Number of PV panels, sweeping area of WT and power of BG generator were the parameters of optimization study. When these values were optimized, the objective function was expected to get the lowest value.

$$
\text { Min.TNPC ( } \left.N_{\text {module }}, A_{w t} P_{b g}\right)=\sum_{i=p v, w t, b g} T N P V_{i}
$$

Constraints of optimization were given in (15)-(18). Estimated values of $N_{\text {module }}, A_{w t}, P_{b g}$ should be remain the following limits:

$$
\begin{aligned}
& N_{\text {module }}^{\text {min }} \leq N_{\text {module }} \leq N_{\text {module }}^{\text {max }} \\
& A_{w t}^{\text {min }} \leq A_{w t} \leq A_{w t}^{\text {max }} \\
& P_{b g}^{\text {min }} \leq P_{b g} \leq P_{b g}^{\text {max }} \\
& L P S P^{\text {min }} \leq L P S P \leq L P S P^{\text {max }}
\end{aligned}
$$

\section{H. Localized Cost of Energy (LCOE)}

At the end of the optimization, the energy cost per $\mathrm{kWh}$ was calculated by LCOE ( $\$ / \mathrm{kWh})$ as given in (19). Here, $E_{l}$ is energy consumption of faculty per year.

$$
L C O E=\frac{T N P C \times C R F}{E_{l}}
$$

Capital recovery factor (CRF) was calculated as in (20):

$$
C R F=\frac{i \times(1+i)^{N}}{(1+i)^{N-1}}
$$

In Fig. 4, work flow of optimization can be seen.

\section{Optimization Algorithm and Software}

For optimization, GA which is meta-heuristic optimization algorithms was used. GA uses rules which contain probability and it gives successful results when the solution space is discontinuous and complex. For parameters of GA; the number of populations was taken 50 , the probability of crossing was taken 0.8 , the probability of mutation was taken 0.05 , and function tolerance was taken 10e-6. Here, function tolerance was used as stopping criteria.

\section{J. Methodology of Optimization Process}

In order to meet the load during the flow of the process, the PV and WT energy were preferred firstly, and when these sources were insufficient, BG generator run. Obtaining of hourly LPS(t) and its methodology were as follows:

\section{Situation:}

$P_{r n}(t) \geq P_{l}(t): P_{r n}(t)$ is the sum of energy produced by $\mathrm{PV}$ and WT and $P_{l}(t)$ is load. If produced energy is enough for meeting consumption, $\operatorname{LPS}(t)$ will be zero.

$$
P_{r n}(t)=P_{p v}(t)+P_{w t}(t)
$$




$$
\operatorname{LPS}(t)=0
$$

$P_{d l}(t)$ is the dump load and occurs when $P_{r n}(t)$ is much more than load.

$$
P_{d l}(t)=P_{r n}(t)-P_{l}(t)
$$

\section{Situation:}

$P_{r n}(t) \leq P_{l}(t)$ : When $P_{r n}(t)$ is insufficient to consumption, deficit load is occurred as $P_{d}(t)$.

$$
P_{d}(t)=P_{r n}(t)-P_{l}(t)
$$

2.1. $P_{d}(t) \geq P_{b g}(t)$, When $P_{r n}(t)$ and $P_{b g}(t)$ cannot meet to consumption together, LPS(t) become as difference between $P_{d}(t)$ and $P_{b g}(t)$.

$$
\operatorname{LPS}(t)=P_{d}(t)-P_{b g}(t)
$$

2.2. $P_{d}(t) \leq P_{b g}(t)$, If energy produced by BG generator is more than deficit power, following situations occurs.

$$
\begin{aligned}
& n(t)=f \operatorname{loor}\left(\frac{P_{d}(t)}{P_{b g n}}\right) \\
& P_{n}(t)=P_{d}(t)-n \times P_{b g n}
\end{aligned}
$$

$P_{n}(t)$ defines the required energy when total energy supply from the hybrid system was not sufficient. If $P_{n}(t) \geq 0.3 \times$ $P_{b g n}$, working BG generator power $\left(P_{b g, h}(t)\right)$ will be equal to $P_{d}(t)$. Otherwise, $P_{b g, h}(t)=n \times P_{b g n}$ and $P_{n}(t)$ will be equal to $\operatorname{LPS}(t) . P_{b g n}$ is the nominal power of $\mathrm{BG}$ generator. BG generator cannot work well when load is less than $30 \%$ of generator nominal power. So, loading coefficient of 0.3 was taken as multiplier.

\section{RESULTS}

Optimization of hybrid systems involving biomass energy in existing studies shows that it is usually done with packet programs. In our study, the inclusion of wind energy in the hybrid system and the evaluation of the LCOE beside TNPC are different from previous studies.

Sizing of the hybrid system was repeated for different economic parameters during the study. MATLAB was used for coding of optimization algorithm. An i7 processor computer consisting of $16 \mathrm{~GB}$ ram and $2 \mathrm{~GB}$ graphics card was utilized to perform optimization process. According to the iteration, changes in TNPC value were given in Fig. 5.

Optimization results were given in Table 5. $N_{\text {module }}, A_{w t}$ and $P_{b g}$ are optimization parameters. As a result of optimization made by the GA, 597 PV panels and 6 pieces of $10 \mathrm{~kW}$ biogas generators must be used. The power equivalent of the panels was given in Table 5.

TABLE V. OPTIMIZATION RESULTS

\begin{tabular}{|l|l|l|l|}
\hline Energy Source & $\begin{array}{l}\text { Optimized } \\
\text { Parameter }\end{array}$ & Result & Power (kW) \\
\hline PV & $N_{\text {module }}$ (pieces) & 596.429 & 158.205 \\
\hline WT & $A_{w t}\left(\mathrm{~m}^{2}\right)$ & 0 & 0 \\
\hline BM & $P_{b g}(\mathrm{~W})$ & 63790.795 & 60 \\
\hline
\end{tabular}

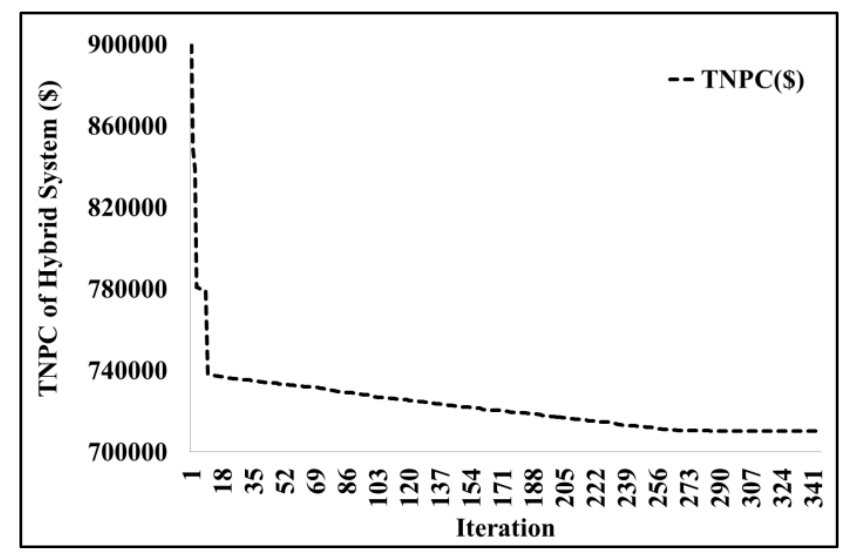

Fig. 5. Changes in TNPC values according to the iteration number.

As shown in Fig. 6, 71\% PV, 29\% BM and 0\% WT were recommended after optimization. As a result of the optimization made by the GA, the WT was not selected as an energy source because the wind speed around Karabuk University is not suitable for investing for efficient wind energy production.

Fig. 7 shows values of TNPC and LCOE, according to the different LPSP values changing between 0.01 and 0.02 . When LPSP increases $1 \%$, LCOE and TNPC increase $24.11 \%$ together. The characteristics of slopes for TNPC and LCOE show increasing trends according to decreasing LPSP values towards to 0. Hence, when LPSP reached to 0, TNPC and LCOE values expected to be much higher.

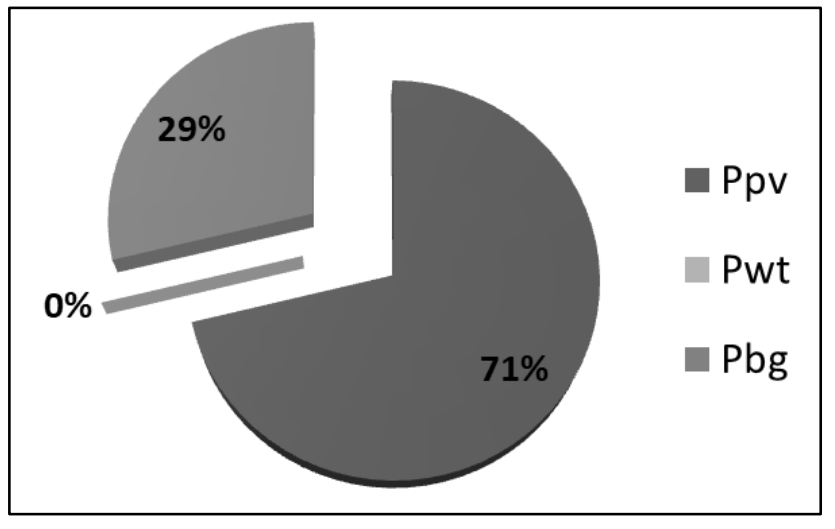

Fig. 6. Rates of power distribution according to the energy sources.

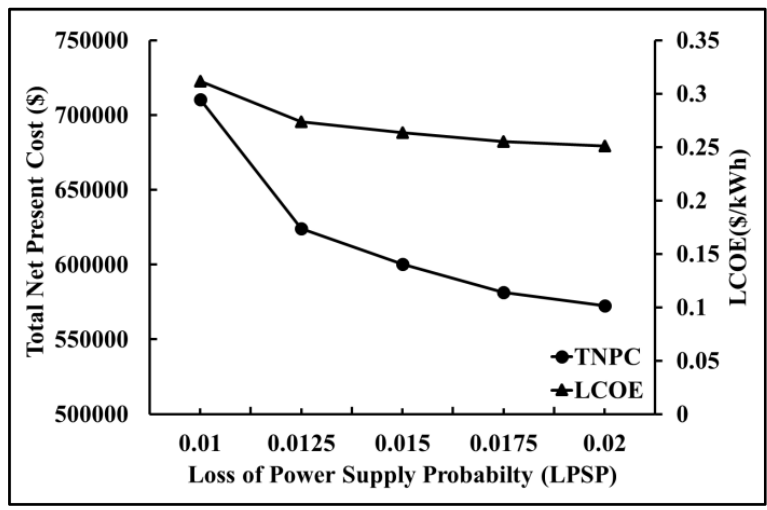

Fig. 7. Changes of TNPC and LCOE values in different LPSP. 
Interest rate in undeveloped and developing countries is not stable as in developed countries. Since Turkey is a developing country, changes in interest rate have an impact on investment costs. Values of TNPC and LCOE, according to different interest rates, were shown in Fig. 8. As interest rate increases from $7 \%$ to $13 \%$, LCOE increases from $0.2778 \$ / \mathrm{kWh}$ to $0.3421 \$ / \mathrm{kWh}$ and TNPC decreases from $\$ 813085$ to $\$ 629685$. In addition, according to the Fig. 8, it's observed that the $\mathrm{LCOE}$ is directly proportional to the interest rate, however the TNPC is inversely proportional with interest rate. Furthermore, a $6 \%$ increase in interest rate provided and increase in LCOE values by $19.5 \%$ and caused a decrease TNPC values by $22.5 \%$.

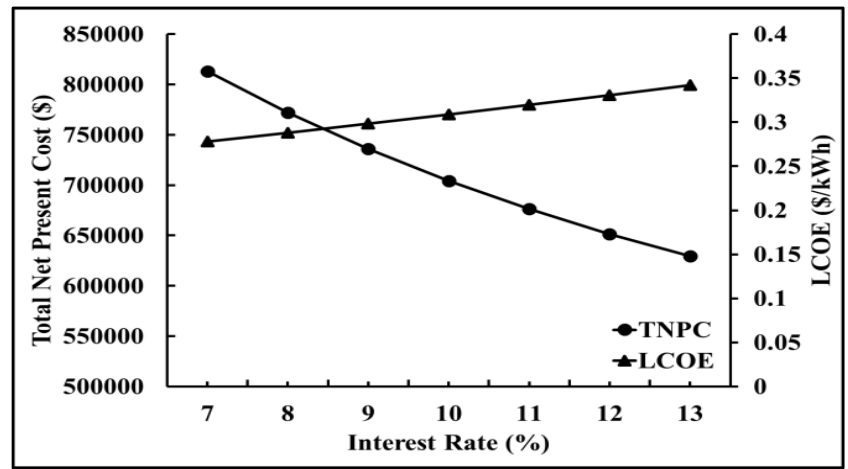

Fig. 8. Values of TNPC and LCOE in different interest rate.

TABLE VI. RESUlTS FOR DIFFERENT INITIAL COST OF PV PANEL

\begin{tabular}{|c|c|c|c|c|c|c|c|}
\hline $\begin{array}{l}\text { Initial Cost of } \\
\text { PV (\$/piece) }\end{array}$ & $\mathrm{TNPC}_{\mathrm{pv}}(\$)$ & TNPC $_{\mathrm{wt}}(\$)$ & $\mathrm{TNPC}_{\text {bg }}(\$)$ & $O M_{p v}(\$)$ & $O M_{b g}(\$)$ & TNPC (\$) & LCOE (\$/kWh) \\
\hline 315 & 240085 & 0 & 415628 & 52611 & 162605 & 655714 & 0.2877 \\
\hline 340 & 245620 & 0 & 427057 & 53825 & 166917 & 672657 & 0.2951 \\
\hline 370 & 251223 & 0 & 445228 & 55051 & 175117 & 696428 & 0.3055 \\
\hline 400 & 267694 & 0 & 448657 & 58662 & 176660 & 716342 & 0.3143 \\
\hline 430 & 285665 & 0 & 452800 & 62600 & 178834 & 738485 & 0.3240 \\
\hline
\end{tabular}

TABLE VII. RESULTS FOR DIFFERENT INITIAL COST OF BIOMASS SYSTEM

\begin{tabular}{|c|c|c|c|c|c|c|c|}
\hline $\begin{array}{l}\text { Initial Cost of BM } \\
(\$ / \mathbf{k W})\end{array}$ & $\mathrm{TNPC}_{\mathrm{pv}}(\$)$ & $\mathrm{TNPC}_{\mathrm{wt}}(\$)$ & $\mathrm{TNPC}_{\mathrm{bg}}(\$)$ & $\mathrm{OM}_{\mathrm{pv}}(\$)$ & $O M_{b g}(\$)$ & TNPC (\$) & LCOE $(\$ / \mathbf{k W h})$ \\
\hline 1700 & 251257 & 0 & 386857 & 55060 & 141562 & 638114 & 0.28 \\
\hline 2000 & 257585 & 0 & 401000 & 56445 & 150225 & 658600 & 0.2889 \\
\hline 2300 & 258154 & 0 & 430857 & 56571 & 166828 & 689028 & 0.3023 \\
\hline 2600 & 260797 & 0 & 460457 & 57151 & 183534 & 721257 & 0.3164 \\
\hline 2900 & 264928 & 0 & 487571 & 58057 & 199054 & 752485 & 0.3301 \\
\hline
\end{tabular}

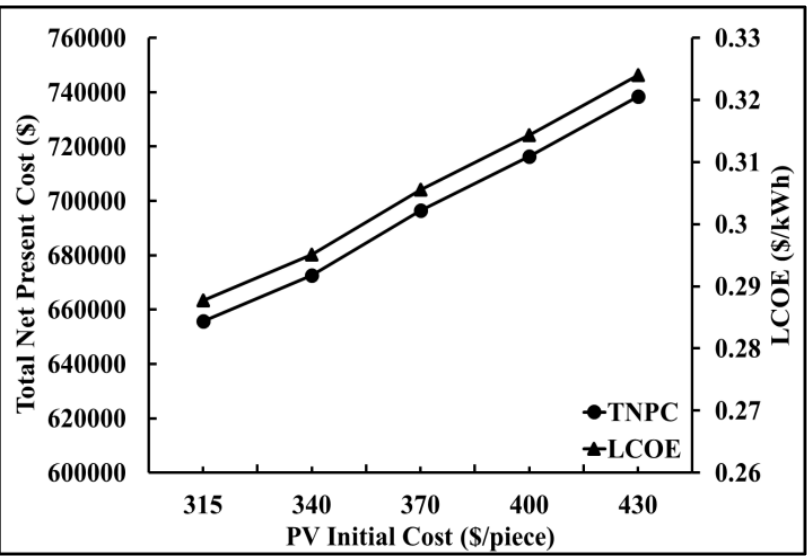

Fig. 9. TNPC and LCOE values according to the changing PV panel cost.

The variation of PV panel investment cost versus LCOE and TNPC was shown in Fig. 9. According to the Fig. 9, when initial cost of PV panel decreases from \$ 430 to $\$ 315$, LCOE decreases from $0.3240 \$ / \mathrm{kWh}$ to $0.2877 \$ / \mathrm{kWh}$ and TNPC decreases from $\$ 738485$ to $\$ 655714$. When initial cost of PV panel decreases $26.7 \%$, LCOE and TNPC decrease $11.2 \%$ together. According to this result, changes in PV panel initial cost have a serious impact on TNPC and LCOE.
In Table 6, TNPC of PV panel, WT, BM system, and operation and maintenance cost of each system for different initial costs of PV panels were listed. According to Table 6, changes in initial cost of PV panel effects the TNPC strongly. It was seen that the investment cost and usage rate of PV panel in hybrid system are inversely proportional. Besides, when PV panel initial cost increases, usage rate and of $\mathrm{BG}$ generator and $\mathrm{TNPC}_{\mathrm{bg}}$ increases.

In Fig. 10, it was seen that as investment cost of the BG system increases, TNPC and LCOE values increases together. When the initial cost of BM system decreases from \$ 2900 to \$ 1700 , LCOE decreases from $0.3301 \$ / \mathrm{kWh}$ to $0.28 \$ / \mathrm{kWh}$ and TNPC decreases from $\$ 752485$ to $\$ 638114$. When initial cost of BM system decreases $41.4 \%$, LCOE and TNPC decrease $15.2 \%$ together. As the cost of BM system investment increases, the results tend towards PV energy usage, so the number of solar panels and $\mathrm{TNPC}_{\mathrm{pv}}$ values increases.

In Table 7, TNPC of PV panel, WT, BM system, and operation and maintenance cost of each system for different initial costs of BM system were demonstrated.

According to Table 7, changes in initial cost of BM system effects to TNPC. The increase in investment cost of the biomass system increased both $\mathrm{TNPC}_{\mathrm{bg}}$ and $\mathrm{TNPC}_{\mathrm{pv}}$. Because when initial cost of BM system increases, usage rate of PV panel increases. 


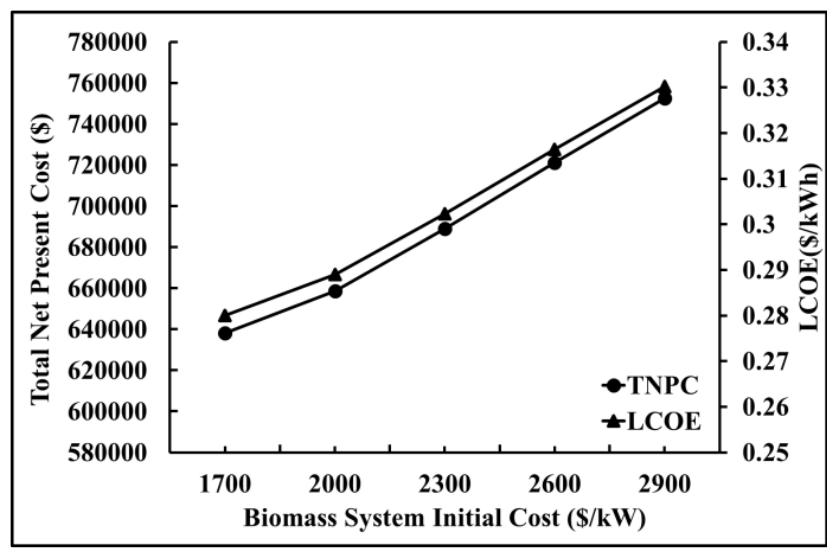

Fig. 10. TNPC and LCOE values according to the changing BM cost.

\section{CONCLUSION}

In the study, size optimization was performed according to the lowest cost and highest reliability to meet the energy requirement of a faculty in Karabuk University Campus with BM supported PV/WT hybrid energy system. GA which is one of the meta-heuristic optimization algorithms was used in current optimization study. TNPC and LCOE values were demonstrated according to the interest rate, $\mathrm{PV}$ and $\mathrm{BM}$ initial cost. As a result, WT energy was not considered as a profitable energy source by GA due to the insufficient wind speed around Karabuk University for an efficient wind energy production. When LPSP was set to 0.1 , recommended sizes of PV power, $\mathrm{BM}$ power and WT power were determined as $71 \%, 29 \%$ and $0 \%$, respectively by GA. In optimized system, power of PV and BM system were determined $158.205 \mathrm{~kW}$ and $63.791 \mathrm{~kW}$, respectively. The TNPC value was $\$ 710285$ and the LCOE value was $0.3117 \$ / \mathrm{kWh}$. As a result, even if WT was not selected as an energy producer by GA, it was proven that supplying the energy demand of faculty by PV and BM effectively is possible. We hope this study will be a favourable case for researchers and engineers who study in hybrid energy and optimization topics. In future studies, optimization of hybrid systems containing biomass energy in terms of economy and reliability can be realised using hybridized metaheuristic algorithms.

\section{REFERENCES}

[1] Healy, N., Barry, J., "Politicizing energy justice and energy system transitions: Fossil fuel divestment and a "just transition"”' Energy Policy, 108:451-459, 2017.

[2] Kayabasi, E., Kurt, H., Celik, E., "Determination of micro sized texturing and nano sized etching procedure to enhance optical properties of n-type single crystalline silicon wafer." Journal of Materials Science: Materials in Electronics, 28(18), pp 14085-14090, 2017.

[3] Celik, A.N., "Techno-economic analysis of autonomous PV-wind hybrid systems using different sizing methods." Energy Conversion and Management, 44 (12), 1951-1968, 2003.

[4] Nasiraghdam, H. Jadid, S., "Optimal hybrid PV/WT/FC sizing and distribution system reconfiguration using multi-objective artificial bee colony (MOABC) algorithm". Solar Energy, 86: 3057-3071, 2012.

[5] McHugh, M.L., "Power analysis in research" Biochemia Medica, 18(3):263-74, 2008.

[6] Lazou, A. A., Papatsoris, A. D., The economics of PV stand-alone residential households: A case study for various European and Mediterranean locations; Solar Energy Materials and Solar Cells, 62:411-427, 2000.
[7] Nas, T.F., Cost Benefit Analysis: Theory and Application, 2nd Edition, Publisher: Rowman \& Littlefield Publishing Group, London, 2016.

[8] Ghazvini, M., Abbaspour-Tehrani-Fard, A., Fotuhi-Firuza Bad, M., "A particle swarm optimization-based approach to achieve optimal design and operation strategy of standalone hybrid energy systems", Turkish Journal of Electrical Engineering \& Computer Sciences. 23: 335 - 353, 2015.

[9] Said. Diaf, Djamila Diaf, Mayouf Belhamel, Mourad Haddadi, Alain Louche, "A methodology for optimal sizing of autonomous hybrid PV/wind system." Energy Policy, Elsevier, 35: 5708-5718, 2007.

[10] Mukhtaruddin, R.N.S.R., Rahman, H.A., Hassan, M.Y., Jamian, J.J, "Optimal hybrid renewable energy design in autonomous system using Iterative-Pareto-Fuzzy technique" Electrical Power and Energy Systems, 64: 242-249, 2015.

[11] Maleki, A., Askarzadeh, A., "Artificial bee swarm optimization for optimum sizing of a stand-alone PV/WT/FC hybrid system considering LPSP concept", Solar Energy, 107:227-235, 2014.

[12] Abouzahr, I., Ramakumar. R. "Loss of power supply probability of stand alone electric conversion systems: a closed form solution approach." IEEE Transaction on Energy Conv. 5(3), 445-452, 1990.

[13] Abdelhak, B.J., Najib, E., Abdelaziz, H., Hnaien, F., Yalaoui, F., Optimum Sizing of Hybrid PV/Wind/Battery Using Fuzzy-Adaptive Genetic Algorithm in real and average battery service life", International Symposium on Power Electronics, Electrical Drives, Automation and Motion 871:876, 2014.

[14] Ho, W.S., Hashim, H., Lim, J.S., "Integrated biomass and solar town concept for a smart eco-village in Iskandar Malaysia (IM)", Renewable Energy, 69:190-201, 2014.

[15] Heydari, A., Askarzadeh, A., "Optimization of a biomass-based photovoltaic power plant for an off-grid application subject to loss of power supply probability concept", Applied Energy, 165:601-611,2016.

[16] Shahzad, M.K., Zehid, A., Rashid, T., Rehan, M.A., Ali, M., Ahmad, M., "Techno-economic feasibility analysis of a solar-biomass off grid system for the electrification of remote rural areas in Pakistan using HOMER software" Renewable Energy, 106: 264-273, 2017.

[17] Bhattacharjee, S., Dey, A., "Techno-economic performance evaluation of grid integrated PV-biomass hybrid power generation for rice mill", Sustainable Energy Technologies and Assessments, 7:6-16, 2014.

[18] Eziyi, I., Krothapalli, A., "Sustainable Rural Development: Solar/Biomass Hybrid Renewable Energy System", Energy Procedia, 57:1492-1501, 2014.

[19] Sigarchian, S.G., Paleta, R., Malmquist, A., Pina, A., "Feasibility study of using a biogas engine as backup in a decentralized hybrid (PV/wind/battery) power generation system-Case study Kenya", Energy, 90: 1830-1841, 2015.

[20] Singh, A., Baredar, P., Gupta, B., "Computational Simulation \& Optimization of a Solar, Fuel Cell and Biomass Hybrid Energy System Using HOMER Pro Software", Procedia Engineering, 127: 743-750, 2015.

[21] Sinha S, Chandel SS. "Review of software tools for hybrid renewable energy systems." Renewable and Sustainable Energy Reviews 32:192205, 2014.

[22] Suganthi, L., Iniyan, S., Samuel, A.A., "Applications of fuzzy logic in renewable energy systems - A review", Renewable and Sustainable Energy Reviews, 48:585-607, 2015.

[23] Merrow, K., Penzien, P., Dubats, T., "Exploring Food Waste Reduction in Campus Dining Halls", The Campus as a Living Laboratory with Dr.Harold Glasser Spring Semestre, Michigan, 2012.

[24] Demirer, G.N., Duran, M., Güven, E., Uğurlu, Ö., Ergüder, R.H., Tezel, U., Şen, S., Korkusuz, E.A., Varolan, N., "Organik Atıklardan Anaerobik Yöntemlerle Biyogaz Eldesi: Türkiye’de Uygulanabilirlik”, Yenilenebilir Enerji Kaynakları Sempozyumu (18-20 Ocak 2001)

[25] Directorate General of Renewable Energy, Biogas, Ministry of Energy and Natural Resources Available: http://www.eie.gov.tr/yenilenebilir/biyogaz.aspx (Accessed: 12.09.2017)

[26] CCRP Report, EPA Climate Change Research Programme 20072013.The Potential for Grass Biomethane as a Biofuel. 
[27] National Renewable Energy Laboratory, "Distributed Generation Renewable Energy Estimate of Costs", Available: https://www.nrel.gov/analysis/tech-lcoe-re-cost-est-2013.html (Accessed: 18.08.2017)

[28] Jim Dunlop Solar, Economic Analysis, Chapter 15-21 (2012)

[29] International Renewable Energy Agency, "Renewable Power Generation Cost In 2014", Available: https://www.irena.org/DocumentDownloads/Publications/IRENA_RE_P ower_Costs_2014_report.pdf (Accessed: 12.06.2017)

[30] Rezanur Rahman, "Feasibility analysis of wood-biomass energy generation for the off-grid community of Brochet in North-west
Manitoba, Canada", The University of Manitoba Faculty of Graduate Studies 2014.

[31] Chedid, R, Akiki, H., Rahman, S., "A DECISION SUPPORT TECHNIQUE FOR THE DESIGN OF HYBRID SOLAR-WIND POWER SYSTEMS", IEEE Transactions on Energy Conversion, Vol. 13, No. 1, 1998.

[32] Gupta, A., Saini, R.P., Sharma, M.P., "Steady-state modelling of hybrid energy system for off grid electrification of cluster of villages", Renewable Energy, 35(2)-520-535, 2010. 